\title{
ポリフェノール含有野菜の高機能化とその応用戦略 一ケルセチン高含有タマネギの健康機能一
}

Quercetin-rich Onion and the Preventive Effects on Lifestyle-related Diseases and Cognitive Decline

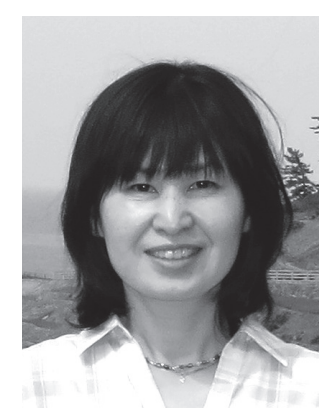

\author{
小堀 真珠子 \\ 国立研究開発法人 農業・食品産業技術総合研究機構 \\ 食品研究部門 食品健康機能研究領域 \\ 食品機能評価ユニット \\ 干 305-8642 \\ 茨城県つくば市観音台 2-1-12 \\ Masuko KOBORI \\ Food Research Institute, National Agriculture \\ and Food Research Organization \\ Tsukuba, Ibaraki 305-8642, Japan
}

論文要旨：フラボノイドはポリフェノールの主要なグループである。コホート研究の結果は, フラボノイ ドのうち，ケルセチン等のフラボノールの摂取が心血管疾患のリスクを下げることを示唆している。日本に おいて, タマネギはケルセチンの主な摂取源であり, 北海道の地域住民を対象とした調査では, ケルセチン の推定摂取量は, 一日当たりケルセチンアグリコンとして $15-16 \mathrm{mg}$ であった。農研機構では, 平成 28 年に ケルセチンを可食部 $100 \mathrm{~g}$ 当たりアグリコンとして $75 \mathrm{mg}$ 含む, ケルセチン高含有タマネギ「クエルゴール ド」を品種登録した。「クエルゴールド」を摂取することによりケルセチンの摂取量を増やすことができる。 認知機能の低下や認知症の発症と食生活との関係が明らかになりつつあるが, ケルセチンは加齢マウスやア ルツハイマー病モデルマウスの認知機能を改善することが明らかになった。介入試験の結果は, ケルセチン 高含有タマネギの摂取が早期アルツハイマー病患者の想起記憶を改善することや, 高齢者の認知機能を改善 し, 認知機能低下を抑えることを示唆しており，ケルセチン高含有タマネギが, 食生活を介して認知機能の 低下や生活習慣病予防に寄与することが期待される。

\begin{abstract}
Flavonols are a class of flavonoids that consist of a large group of polyphenols. Epidemiological studies have suggested that flavonols, including quercetin, have a protective effect against cardiocascular diseases. Onions are the major food source of quercetin in Japan. The mean estimated quercetin intakes by residents of a town in Japan were 15-16 mg (as quercetin aglycon) / day in summer and winter. Recently, quercetin-rich onion 'Quergold' containing about $75 \mathrm{mg}$ quercetin / $100 \mathrm{~g}$ of fresh weight in the edible portion is registered. Dietary patterns have been reported to be associated with risks of dementia and Altzheimer's diseases. Dietary administration of quercetin was shown to improve the cognitive function in both Altzheimer's disease model mice and healthy aged mice. The results of intervention trials suggested that consumption of quercetin rich onion improved memory recall in early-stage Alzheimer's patients, and cognitive function in elderly people. Quercetin-rich onion is expected to be contribute to prevent lifestyle-related diseases and cognitive decline through dietary life.
\end{abstract}

Key words: onion, quercetin, flavonoids, lifestyle-related diseases, cognitive function 


\section{1 はじめに}

欧米の前向きコホート研究で，ポリフェノールのうち のフラボノイド, 特にケルセチンやケンフェロールと いったフラボノール等の摂取が，心血管疾患による死亡

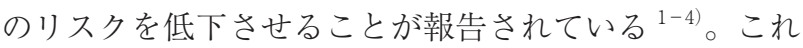
らの研究では, 食事調査と食品中の成分含量からフラボ ノイド等の摂取量を推定して, 疾病リスクとの関係を解 析しており，その結果は，食事の評価法や採用する成分 含量データにも依存する。現在, 食品中のポリフェノー ルに関するデータベースとして Scarbertらが開発した Phenol-Explorer ${ }^{5)}$ や米国農務省の USDA Database for the Flavonoid Content of Selected Foods 等が公開され ているが, 野菜や果物等の食品素材に含まれるポリフェ ノールの含量は, 品種や栽培地域, 収穫時期等, 様々な 要因により変動する。これらのことから, ポリフェノー ルと疾病リスクとの関係を明らかにするコホート研究の 例はまだ多くなく，関連性なし，とする結果もある ${ }^{6,7) 。 ~}$ 最近ではより正確な評価を目指して, ポリフェノールの 摂取の目安となるバイオマーカーによる評価も検討され ている ${ }^{8,9)}$ 。しかしながら, 食事からフラボノイドを多 く摂取することにより，心血管疾患のリスクが低下した ことは, フラボノイドを多く含む野菜や果物, 茶等の飲 料の摂取が生活習慣病予防に有効であることを示す極め て重要な結果である。

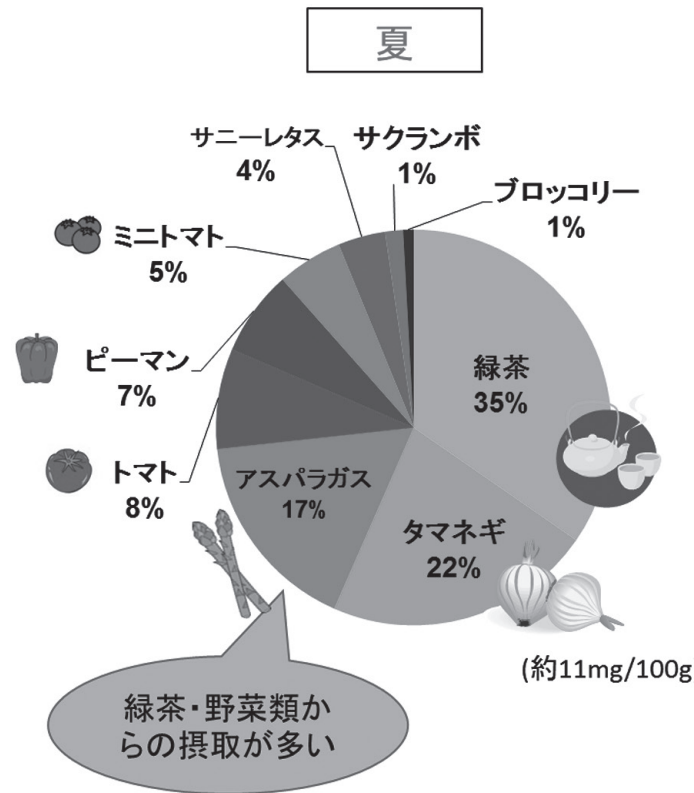

\section{2 食事から摂取するフラボノイドとその健康機能}

我が国においては，東北地域の女性を対象とした，食 事記録と食品中のフラボノイドの分析結果に基づく調査 で, タマネギが主なフラボノイドの摂取源であること， またフラボイドの総摂取量やケルセチンの摂取量が多い と血中の総コレステロール量や LDL-コレステロール量

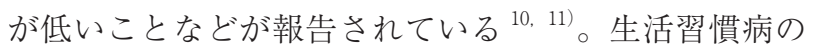
発症には，酸化ストレスや組織における慢性炎症が大き く関わっている。ケルセチンは野菜, 果物, 茶等に広く 含まれており, 抗酸化作用や抗炎症作用が強く, 動物乇 デル等でメタボリックシンドロームや糖尿病等の生活習 慣病予防効果を示す ${ }^{12-16)}$ 。私たちはケルセチンの健康 機能に着目し, 札幌医科大学で実施しているコホート研 究と連携して, 北海道の地域住民を対象としたケルセチ

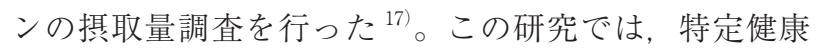
診断の対象者を主として食事摂取頻度調査を行うと共 に, 調査地域で食されている様々な食品についてケルセ チン含量を測定して, ケルセチンの摂取量推定を行っ た。ケルセチンは種々の配糖体として食品中に含まれ る。そこで食事調査の時期に合わせて野菜, 果物, 茶等 の食品を入手し, 配糖体を加水分解してケルセチンの総 量を分析した ${ }^{18)}$ 。その結果, 夏季においては, 緑茶や タマネギの他, アスパラガス, トマト等の夏野菜が主要 なケルセチンの摂取源となっていること, また冬季にお いては, 特にタマネギが主要なケルセチンの摂取源であ ることが明らかになった（Fig. 1)。最近のポリフェノー

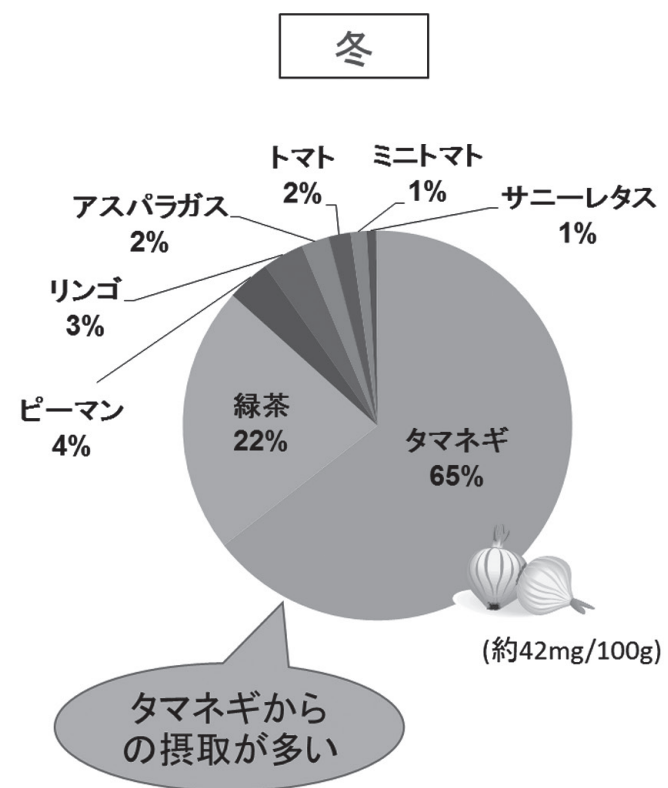

\section{タマネギはケルセチンの主要な㩒取源}

Fig. 1 北海道地域住民を対象とした調査において, ケルセチン摂取に寄与していた夏季及び冬季の食品 ${ }^{17)}$ (巻頭カラー写真参照) 


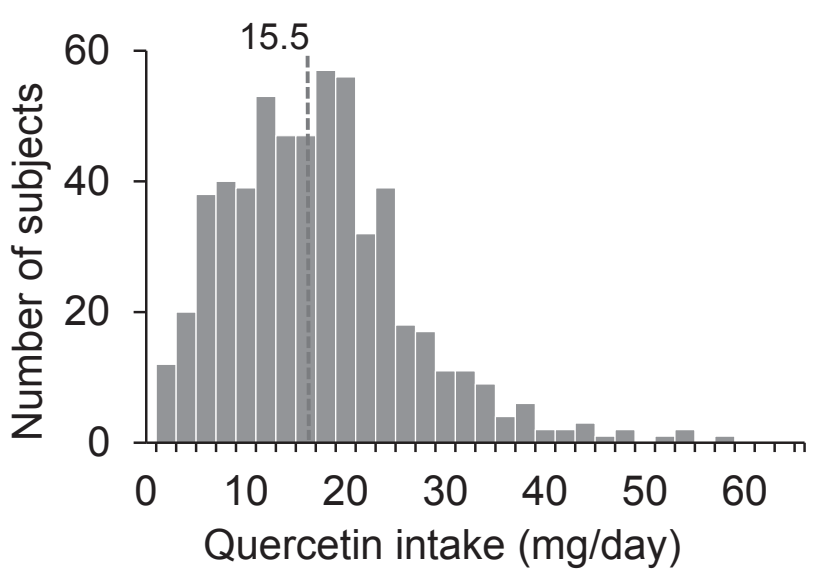

Fig. 2 北海道地域住民（570名）を対象とした夏季におけ る調査で推定されたケルセチンの摂取量 ${ }^{17)}$

ル摂取量に関する調査研究においても, タマネギは日本 人の主要なポリフェノール摂取源の一つであることが報 告されている ${ }^{19,20)}$ 。また，一日あたりのケルセチンの 摂取量の中央值は夏季において $15.5 \mathrm{mg}$, 冬季において $16.1 \mathrm{mg}$ であり, 女性の方がやや摂取量が多く, また年 齢が高いほど摂取量が多い傾向にあった（Fig. 2)。さら に健康機能との関係では, ケルセチン摂取量が多いと拡 張期血圧が低い傾向にあることが示された。

日本のタマネギは可食部 $100 \mathrm{~g}$ 中に約 10-50 mg のケ ルセチンを含んでいる。このうち冬に供給される北海道 産のタマネギは可食部 $100 \mathrm{~g}$ 中に約 30-50 mg のケルセ チンを含んでおり，私たちが測定した際も，タマネギの ケルセチン含量は夏季では少なく, 冬季において多かっ た。また，夏季において，ルチノースの配糖体であるル チンを含むアスパラガスやサニーレタス等の緑黄色野菜 類にもケルセチンが多く含まれていた。

\section{3 ケルセチンを高含有するタマネギ品種の育成}

上記のように，タマネギは主要なポリフェノールの摂 取源の一つであり，ケルセチンの摂取に最も寄与する野 菜である。タマネギの可食部に含まれるケルセチンの配 糖体は主としてケルセチン -4'-グルコシドとケルセチン -3,4'-ジグルコシドであり, 吸収されて血中では抱合体や メチル化体等の代謝産物として見出される（Fig. 3A $)^{21)}$ 。

食生活を介してケルセチンの摂取に寄与できる，ケル セチン配糖体を高含有する夕マネギ品種の育成は比較的 早くから着手されていた。国内のタマネギ品種は北海道 で栽培される春まき栽培品種と本州以南で栽培される秋 まき栽培品種に大別され，春まき栽培品種の方がケルセ チン含量が多いことが報告されている ${ }^{22)}$ 。農業・食品 産業技術総合研究機構 (農研機構) 北海道研究センター の室らは，ケルセチンを特に多く含むが，球が極端に小
A<smiles>[R]Oc1c(-c2ccc(OC)c(O)c2)oc2cc(O)cc(O)c2c1=O</smiles>

B

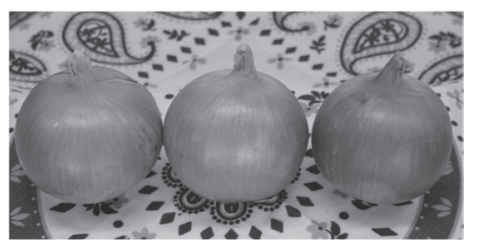

Fig. 3 タマネギに含まれるケルセチン配糖体（A）とケル セチン高含有タマネギ「クエルゴールド」（B）（巻頭 カラー写真参照)

さい, 病気に弱い等の特徵がある品種を見出し, それら を素材として，新たに北海道での栽培に適したケルセチ ンを豊富に含むタマネギ品種「クエルゴールド」を開発 した（Fig. 3B）。平成 28 年 6 月に品種登録された「ク エルゴールド」のケルセチン含量は可食部 $100 \mathrm{~g}$ 中に約

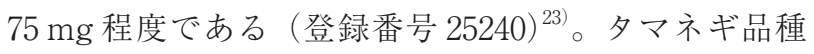
のケルセチン含量は年次間で変動するが, 品種間の相対 的な関係は維持されており,「クエルゴールド」は国内 で栽培されるタマネギの中で, 最も多くケルセチンを含 んでいる。その味は一般的な品種と殆ど変わらないが, 球の大きさは 2 割程度小さく, 乾物率がやや多めで加熱 調理・加工等に適しているという特徵がある。先に述べ た通り, 一日のケルセチンの摂取量は $15 \mathrm{mg}$ 程度と推 定され，50-100 g の「エルゴールド」の摂取で，ケル セチンの摂取量は 3-6 倍に増加する。最近の研究では, 農研機構東北農業研究センターを中心とした研究コン ソーシアムで開発した冬春まき作型を応用することによ り，東北地域等，北海道以外でもケルセチンを高含有す る特性を維持した「クエルゴールド」の栽培が可能であ ることが示された。

\section{4 ケルセチン及びタマネギの生活習慣病予防効果}

ケルセチンの生活習慣病予防効果はサプリメントを用 いた介入試験でも検討され, 血圧低下作用や血中脂質改 善作用等を示すことが報告されている。例えば, Egert らは $150 \mathrm{mg}$ のケルセチンを含むカプセルを 6 週間摂取 することにより BMI 25 以上の太り過ぎの人（overweight）の収縮期血圧及び酸化 LDL 值が下がること, また $162 \mathrm{mg}$ のケルセチンを含むタマネギの皮の抽出物 を6 週間摂取することにより太り過ぎから肥満 (obesity, BMI 30 以上）の高血圧患者の収縮期血圧が下がること を報告している ${ }^{24-26)}$ 。また, Lee らは $100 \mathrm{mg}$ のケルセ 
チンを含むカプセルを 10 週間摂取した喫煙男性で，血 清総コレステロール值, LDL コレステロール值, 血糖值 及び，収縮期及び拡張期血圧が低下したこと， Pfeuffer らは $150 \mathrm{mg}$ のケルセチンを 8 週間摂取した健常男性で, 腹囲，収縮期血圧，血中トリアシルグリセロールが低下 し， HDL コレステロールが増加したことを報告してい るが, 一方で, Javadi らは $500 \mathrm{mg}$ のケルセチンを 8 週 間摂取した関節リウマチの女性では，酸化ストレスマー カー及び血圧に変化はなかったとしている ${ }^{27-29)}$ 。メ夕 アナリシスの結果として, Serbanらはケルセチンのサ プリメントは血圧を低下させるが，その作用は限定的， あるいは 1 日 $500 \mathrm{mg}$ 以上で有効だろうと, 結論づけて いる ${ }^{30)}$ 。またケルセチンを主とするフラボノールのサ プリメントが血圧，血中脂質，血糖值等に及ぼす影響を 検討した介入試験のメタアナリシスの結果は, 主にアジ アの国々において，脂質異常症等の病者を対象とした場 合に，トータルコレステロール，LDL-コレステロール， トリグリセリド，血糖值及び血圧の低下や HDL- コレス トロールの増加が認められる，としている ${ }^{31) 。 サ フ ゚ リ ~}$ メントとしてのケルセチンの摂取量は, 食品から摂取可 能な量に比べて多く, 主に正常值を超えた病者において 有効性が認められている。

一方，介入試験により夕マネギの有効性を示す結果は 極めて少ない。Nakayamaらは, $51 \mathrm{mg}$ のケルセチンを 含むタマネギ抽出物 $4.3 \mathrm{~g}$ を 30 日間摂取することにより, 血管内皮機能のマーカーである FMD（flow-mediated vasodilation，血流依存性血管拡張機能）の食後の值が 改善されることを報告している ${ }^{32)}$ 。

\section{5 ケルセチン高含有タマネギの認知機能改善効果}

認知症は要介護状態に至る主な原因であり，最近の調 査では，日本において 462 万人，65才以上の人口の約 15\%が認知症を患っていると推定されている。超高齢社 会の現在では，生活の質の維持・向上へとつながる，認 知機能を改善し，その低下を予防する食品に，大きな期 待が寄せられている。認知症の主な原因であるアルツハ イマー病には未だ確立された治療法がない。しかし生活 習慣病が認知症の発症に関わることが明らかになりつつ あり，食生活を介した認知症の予防や治療への期待も大 きい。岐阜大学の中川らは, 食生活と関わりの深い GCN2 によるアミノ酸センサーシグナルを介してアルッ ハイマー原因物質アミロイド $\beta$ を産生する新たなアル ツハイマー病の発症メカニズムを明らかにし，培養細胞 を用いた試験でケルセチンがこの経路を抑制することを 明らかにした ${ }^{33)}$ 。ケルセチンを添加した飼料をアルツ ハイマー病モデルマウス及び正常加齢マウスにそれぞれ
長期摂取させ，認知機能を評価する試験として，音を聞 かせて電気ショックを与える恐怖条件付け試験を行う と, ケルセチンを含む飼料を摂取したマウスでは，通常 飼料を摂取したマウスに比べて音を聞いた時の恐怖反応 （すくみによる静止行動）を示す時間が長くなり，アル ツハイマー病モデルマウスばかりでなく正常加齢マウス においても記憶学習機能の改善効果が認められることが 明らかになった ${ }^{34,35)}$ 。作用メカニズムの検討では，ケ ルセチンはアミノ酸センサーシグナル経路に存在する $\mathrm{elF} 2 \alpha$ のリン酸化を抑制してアミロイド $\beta$ 産生経路を抑 制することが示唆されている。

そこで，私たちはこの効果に着目し，連携して，アル ツハイマー病患者及び高齢者ボランティアを対象とし た, ケルセチン高含有タマネギの認知機能改善効果を明 らかにするための介入試験を実施した。

「クエルゴールド」を含む一般的な黄タマネギに対し， 白タマネギはケルセチンを殆ど含まないことが明らかに なっている ${ }^{22)}$ なクエルゴールド」を主とするケルセチ ン高含有タマネギを加熱乾燥粉末とした試験食品と, 白 タマネギを加熱乾燥粉末としたプラセボ食品を作成し て, 成分分析した結果, ケルセチン配糖体を多く含む試 験食品に対し，プラセボ食品はケルセチン配糖体を殆ど 含まないが，タマネギに特徴的な硫黄化合物は試験食品 と同程度含んでいた ${ }^{35)}$ 。中川らは, これらの試験食品 を用い, 発症早期のアルツハイマー病患者を対象として, ケルセチン約 $80 \mathrm{mg}$ に相当する $18 \mathrm{~g}$ の試験食品と同量 のプラセボ食品を，それぞれを 4 週間摂取する介入試験 を実施した。改定長谷川式簡易知能評価は，認知症のス クリーニングに使用される日本で作成された検査であ る。年歯, 単語の復唱, 計算, 数詞の逆唱等についてロ 頭で質問し，被験者に回答させることにより，認知機能 の評価を行う。軽度から中程度の認知障害を認める 5 名 の患者に対して, 試験食品又はプラセボ食品の摂取前後 で長谷川式簡易知能評価を行った結果, 試験食品摂取後 にのみ，単語等を思いださせる想起評価項目の点数が有 意に増加することが明らかになった $\left(\right.$ Fig. $\left.4^{35,36)}\right)$ 。また アルツハイマー病患者 2 名はケルセチン高含有タマネギ 粉末を 1 年 6 か月以上の長期にわたって摂取しているが, うち 1 名の想起評価項目の点数は維持されており，特に 有害事象も認められていない。これらのことから，ケル セチン高含有タマネギの摂取がアルツハイマー病患者に おいて想起記憶を改善する可能性が示された。

北海道情報大学の西平らは，高龄者を対照とした介入 試験を実施した。対象被験者として健常者および軽度の 認知機能低下が認められる 65 歳から 84 歳の男女を, 試 験食品摂取群とプラセボ食品摂取群各 30 名の 2 群に分 


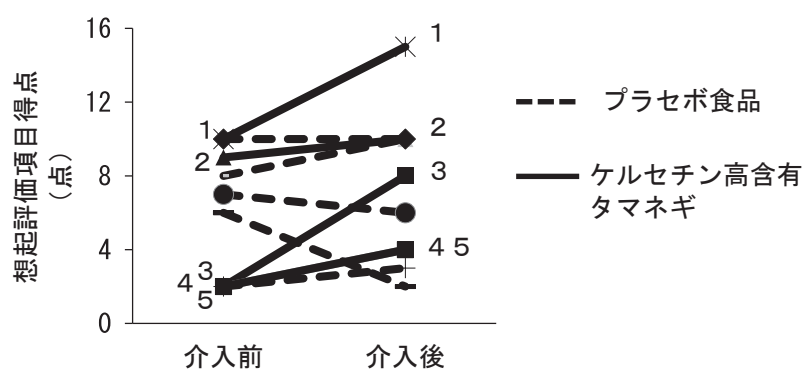

Fig. 4 早期アルッハイマー病患者を対象とした介入試験に 打ける改定長谷川式簡易知能評価の結果 ${ }^{35,36)}$ 。想起 評価項目（3 単語，5つの品物，野菜の名称）におい て，ケルセチン高含有タマネギ摂取後に点数が有意 に増加した。

け，信頼性の高いプラセボ対照 2 重盲検平行群間比較試 験を実施した ${ }^{37)}$ 。摂取期間は 24 週間とし, 長期に摂取 することから, 試験食品の 1 日の摂取量はケルセチン約 $50 \mathrm{mg}$ が摂取できる $10 \mathrm{~g}$ とした。ミニメンタルステー 卜検査は一般的に使用される認知機能検査である。見当 識（「今日は何月何日か」などの自分が置かれている状 況の認識), 記憶力, 計算力等について口頭で質問し, 被験者に回答させて評価する。試験食摂取開始時, 12 週後および 24 週後にミニメンタルステート検査，およ び早期記憶, 遅延記憶等の認知機能評価尺度を用いた評 価を行い, 合わせて副次評価項目として協力者アンケー 卜及び血液検査（脂質, 血糖, 酸化マーカー) を実施し た。その結果, 全被験者で解析すると有意な変化は認め られなかったものの, 年齢中央值で分けたときの年齢が 若い群で, 試験食品を 24 週間摂取することによりミニ メンタルステート検査の点数が有意に改善することが明 らかになった $\left(\right.$ Fig. $\left.5^{36)}\right)$ 。またその他の認知機能検査で は有意差は認められなかったものの, このことはケルセ チン高含有タマネギの摂取が高齢者の認知機能を改善す る可能性を示している。また興味深いことに, 協力者の アンケート結果では「症状の重症度」や「協力者の負担 度」が改善傾向にあり, 認知機能の低下で問題となる介
護者への負担軽減を示唆する結果も得られた。これらの 有効性を明らかにするために更なる検討が必要と考えら える。

\section{6 ケルセチンの生体利用性を高めるタマネギの摂取方法}

ケルセチンは比較的安定な化合物であり, 調理 - 加工 してもあまり失われることはない。加熱乾燥粉末に加工 しても, タマネギ中にはほぼ相当量の配糖体が保持され ていた。タマネギから摂取したケルセチンは, 代謝され て, メチル化体や, グルクロン酸, 硫酸が結合した抱合 体として血中に見出される。徳島大学(現甲南女子大学) の寺尾らは, 健常者を用いた介入試験により, タマネギ の摂取方法や食べ合わせによるケルセチンの生体利用性 の変化を検討し, フライタマネギの方がレンジ加熱した タマネギより血漿中のケルセチン濃度が上昇すること, またソテーにしたタマネギを豆腐と同時摂取することに より，血漿中のケルセチン代謝物のパターンが変化する こと等を明らかにした ${ }^{21)}$ 。血中のケルセチン濃度を高 める食べ合わせに関する研究も含めて, ケルセチンの摂 取に有効なタマネギの調理方法や献立を明らかにする研 究が進められている。

\section{7 おわりに}

ケルセチン高含有タマネギ「クエルゴールド」は, 平 成 27 年 12 月よりインターネットで種子販売されている (http://ikushu.com/archives/874)。コホート研究や摂 取量調査, 摂取方法等に関する研究の結果は, ケルセチ ン高含有タマネギが食生活を介した生活習慣病予防に有 用であることを示している。しかし，同品種を普及させ るためには, 介入試験等によりその健康機能をより明確 にし，有効な摂取量を提示して機能性表示すること等に より高機能野菜としての高付加価值化を実現することも 重要だろう。すでにフラボノイドのうち, 大豆に特徵的 に含まれるイソフラボンが骨代謝に及ぼす影響に着目し
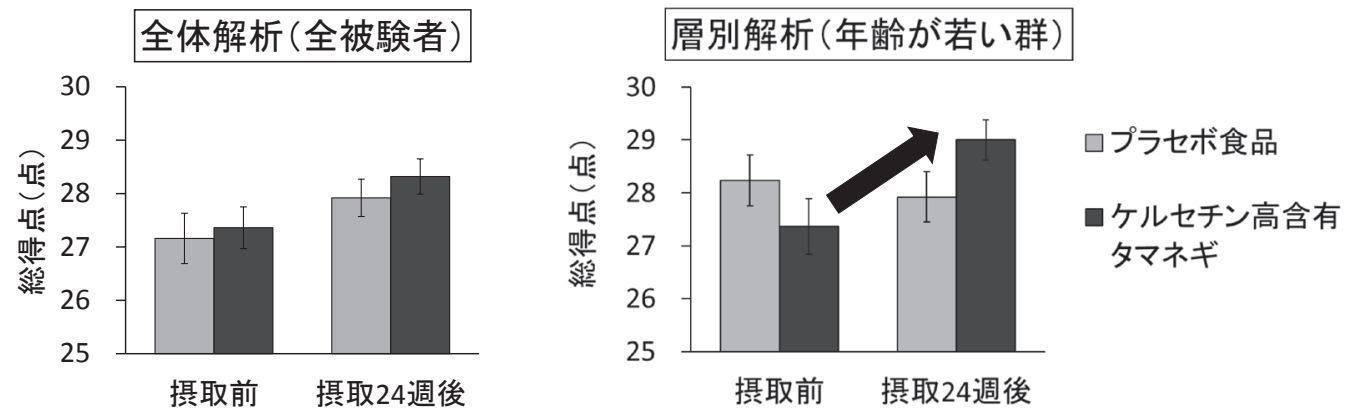

Fig. 5 高齢者を対象とした介入試験におけるミニメンタルステート検査の結果 ${ }^{36,37}$ 。全被験者による全体解析では有意な変化は 認められないが, 年齢中央值で分けた層別解析では, 年龃が若い群でケルセチン高含有タマネギ摂取 24 週後に有意に得 点変化量が上昇した。 
た，大豆もやしが機能性表示食品として販売されてい る。介入試験の結果は, ケルセチン高含有タマネギの摂 取が認知機能改善に有用であることを示唆しており，更 なる解明が望まれる。またアスパラやグリーンレタスに もケルセチン配糖体が多く含まれていたように，ポリ フェノールを高含有し，健康機能性を有する他の野菜品 種の開発も期待でき，それらを取り入れることによって 健康に寄与する食生活をより豊かにすることも可能だろ う。

\section{謝辞}

第 $2 ， 3 ， 5$ 及び 6 章に記載した一部あるいは多くの研 究は, 農林水産省委託「農林水産資源を活用した新需要 創出プロジェクト」, 農研機構「機能性をもつ農林水産物・ 食品開発プロジェクト」により行われたものである。

\section{文 献}

1) Knekt, P.; Kumpulainen, J.; Jarvinen, R.; Rissanen, H.; Heliovaara, M.; Reunanen, A.; Hakulinen, T.; Aromaa, A. Am. J. Clin. Nutr., 76, 560-568 (2002).

2) Arts, I. C.; Hollman, P. C. Am. J. Clin. Nutr., 81, 317S325S (2005).

3) McCullough, M. L.; Peterson, J. J.; Patel, R.; Jacques, P. F.; Shah, R.; Dwyer, J. T. Am. J. Clin. Nutr., 95, 454464 (2012).

4) Peterson, J. J.; Dwyer, J. T.; Jacques, P. F.; McCullough, M. L. Nutr. Rev., 70, 491-508 (2012).

5) Neveu, V.; Perez-Jimenez, J.; Vos, F.; Crespy, V.; du Chaffaut, L.; Mennen, L.; Knox, C.; Eisner, R.; Cruz, J.; Wishart, D.; Scalbert, A. Database (Oxford), 2010, bap024 (2010).

6) Wang, Y.; Chun, O. K.; Song, W. O. Nutrients, 5, 29693004 (2013).

7) Lin, J.; Rexrode, K. M.; Hu, F.; Albert, C. M.; Chae, C. U.; Rimm, E. B.; Stampfer, M. J.; Manson, J. E. Am. J. Epidemiol., 165, 1305-1313 (2007).

8) Zamora-Ros, R.; Touillaud, M.; Rothwell, J. A.; Romieu, I.; Scalbert, A. Am. J. Clin. Nutr., 100, 11-26 (2014).

9) Rienks, J.; Barbaresko, J.; Nothlings, U. Nutrients, 9 (4), pii: E415 (2017)

10) Arai, Y.; Watanabe, S.; Kimira, M.; Shimoi, K.; Mochizuki, R.; Kinae, N. J. Nutr., 130, 2243-2250 (2000)

11) Otaki, N.; Kimira, M.; Katsumata, S.; Uehara, M.; Watanabe, S.; Suzuki, K. J. Clin. Biochem. Nutr., 44, 231-238 (2009).

12) Terao, J.; Kawai, Y.; Murota, K. Asia Pac. J. Clin. Nutr., 17 Suppl. 1, 291-293 (2008).

13) Morales, J.; Gunther, G.; Zanocco, A. L.; Lemp, E. PLoS One, 7, e40548 (2012)

14) Kobori, M.; Masumoto, S.; Akimoto, Y.; Takahashi, Y. Mol. Nutr. Food Res., 53, 859-868 (2009).

15) Kobori, M.; Masumoto, S.; Akimoto, Y.; Oike, H. Mol.
Nutr. Food Res., 55, 530-540 (2011).

16) Kobori, M.; Takahashi, Y.; Sakurai, M.; Akimoto, Y.; Tsushida, T.; Oike, H.; Ippoushi, K. Mol. Nutr. Food Res., 60, 300-312 (2016).

17) Nishimuro, H.; Ohnishi, H.; Sato, M.; Ohnishi-Kameyama, M.; Matsunaga, I.; Naito, S.; Ippoushi, K.; Oike, H.; Nagata, T.; Akasaka, H.; Saitoh, S.; Shimamoto, K.; Kobori, M. Nutrients, 7, 2345-2358 (2015).

18) Watanabe, J.; Takebayashi, J.; Takano-Ishikawa, Y.; Yasui, A. Anal. Sci., 28, 1179-1182 (2012).

19）田口千絵, 岸本良美, 福島洋一, 才田恵美, 田中未央里, 近藤和雄. 日本栄養·食糧学会誌, 70, 17-22 (2017).

20) Taguchi, C.; Fukushima, Y.; Kishimoto, Y.; Suzuki-Sugihara, N.; Saita, E.; Takahashi, Y.; Kondo, K. Nutrients, 7, 10269-10281 (2015).

21) Nakamura, T.; Murota, K.; Kumamoto, S.; Misumi, K.; Bando, N.; Ikushiro, S.; Takahashi, N.; Sekido, K.; Kato, Y.; Terao, J. Mol. Nutr. Food Res., 58, 310-317 (2014).

22）岡本大作, 野口裕司, 室崇人, 森下昌三。園芸学雑誌, 75, 100-108 (2006).

23）室崇人, 嘉見大介, 杉山慶太. 園芸学研究, 14, 305311 (2015)

24) Egert, S.; Bosy-Westphal, A.; Seiberl, J.; Kurbitz, C.; Settler, U.; Plachta-Danielzik, S.; Wagner, A. E.; Frank, J.; Schrezenmeir, J.; Rimbach, G.; Wolffram, S.; Muller, M. J. Br. J. Nutr., 102, 1065-1074 (2009).

25) Egert, S.; Boesch-Saadatmandi, C.; Wolffram, S.; Rimbach, G.; Muller, M. J. J. Nutr., 140, 278-284 (2010).

26) Brull, V.; Burak, C.; Stoffel-Wagner, B.; Wolffram, S.; Nickenig, G.; Muller, C.; Langguth, P.; Alteheld, B.; Fimmers, R.; Naaf, S.; Zimmermann, B. F.; Stehle, P.; Egert, S. Br. J. Nutr., 114, 1263-1277 (2015).

27) Lee, K. H.; Park, E.; Lee, H. J.; Kim, M. O.; Cha, Y. J.; Kim, J. M.; Lee, H.; Shin, M. J. Nutr. Res. Pract., 5, 28-33 (2011).

28) Pfeuffer, M.; Auinger, A.; Bley, U.; Kraus-Stojanowic, I.; Laue, C.; Winkler, P.; Rufer, C. E.; Frank, J.; Bosch-Saadatmandi, C.; Rimbach, G.; Schrezenmeir, J. Nutr. Metab. Cardiovasc. Dis., 23, 403-409 (2013).

29) Javadi, F.; Eghtesadi, S.; Ahmadzadeh, A.; Aryaeian, N.; Zabihiyeganeh, M.; Foroushani, A. R.; Jazayeri, S. Int. J. Prev. Med., 5, 293-301 (2014).

30) Serban, M. C.; Sahebkar, A.; Zanchetti, A.; Mikhailidis, D. P.; Howard, G.; Antal, D.; Andrica, F.; Ahmed, A.; Aronow, W. S.; Muntner, P.; Lip, G. Y.; Graham, I.; Wong, N.; Rysz, J.; Banach, M.; Lipid; Blood Pressure Meta-analysis Collaboration G. J. Am. Heart Assoc., 5 (7), pii : e002713 (2016)

31) Menezes, R.; Rodriguez-Mateos, A.; Kaltsatou, A.; Gonzalez-Sarrias, A.; Greyling, A.; Giannaki, C.; AndresLacueva, C.; Milenkovic, D.; Gibney, E. R.; Dumont, J.; Schar, M.; Garcia-Aloy, M.; Palma-Duran, S.A.; Ruskovska, T.; Maksimova, V.; Combet, E.; Pinto, P. Nutrients, 9 (2), 117 (2017).

32) Nakayama, H.; Tsuge, N.; Sawada, H.; Higashi, Y. J. Am. Coll. Nutr., 32, 160-164 (2013). 
33) Ohta, K.; Mizuno, A.; Ueda, M.; Li, S.; Suzuki, Y.; Hida, Y.; Hayakawa-Yano, Y.; Itoh, M.; Ohta, E.; Kobori, M.; Nakagawa, T. Autophagy, 6, 345-352 (2010).

34) Hayakawa, M.; Itoh, M.; Ohta, K.; Li, S.; Ueda, M.; Wang, M. X.; Nishida, E.; Islam, S.; Suzuki, C.; Ohzawa, K.; Kobori, M.; Inuzuka, T.; Nakagawa, T. Neurobiol. Aging, 36, 2509-2518 (2015).

35) Nakagawa, T.; Itoh, M.; Ohta, K.; Hayashi, Y.; Hayakawa, M.; Yamada, Y.; Akanabe, H.; Chikaishi, T.; Nak- agawa, K.; Itoh, Y.; Muro, T.; Yanagida, D.; Nakabayashi, R.; Mori, T.; Saito, K.; Ohzawa, K.; Suzuki, C.; Li, S.; Ueda, M.; Wang, M. X.; Nishida, E.; Islam, S.; Tana; Kobori, M.; Inuzuka, T. Neuroreport, 27, 671-676 (2016).

36）小堀真珠子. JATAFF ジャーナル, 4(12), 26-30(2016).

37) Nishimura, M.; Ohkawara, T.; Nakagawa, T.; Muro, T.; Sato, Y.; Satoh, H.; Kobori, M.; Nishihira, J. Funct. Food Health Dis. 7, 353-374 (2017). 